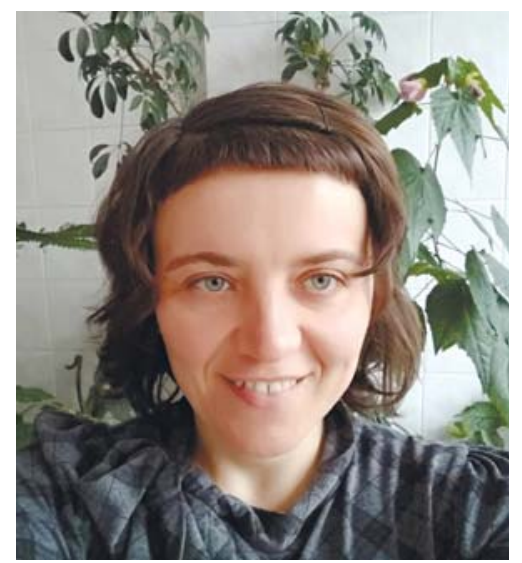

ЯВIP

Віра Анатоліївна -

доктор політичних наук,

провідний науковий

співробітник Інституту держави

і права ім. В.М. Корецького НАН України

\section{ІНТЕГРАЦІЯ ТА ДЕЗІНТЕГРАЦІЯ ДЕРЖАВИ ЯК ВИКЛИК ДЛЯ ЕТНОНАЦІОНАЛЬНОЇ ПОЛІТИКИ УКРАЇНИ}

\author{
За матеріалами доповіді на засіданні \\ Президії НАН України 7 липня 2021 року
}

Досліджено інтенсифікацію процесів етнополітичної інтегращї та дезінтеграції у сучасному світі, їх діалектичний взаємозв'язок та взаємозумовленість. Розкрито передумови, чинники та особливості відкритої фази етнополітичної дезінтеграчії України, яка розпочалася в 2014 р. Розглянуто прояви дезінтеграційних викликів, які становлять загрозу територіальній цілісності держави, зокрема втручання у внутрішні справи України сусідніх країн (Угорщини, Російсъкої Федераціі) під приводом захисту прав національних меншин. Проаналізовано процес етнополітичної реінтеграціі та обгрунтовано розгляд політики реінтеграцї в контексті державної етнонаціональної політики України. Досліджено сучасний стан, правову базу, політичні особливості реінтеграцї, а також запропоновано рекомендащї для проведення успішної реінтегращї тимчасово окупованих територій Криму та Донбасу.

Характерною тенденцією сучасності є інтенсифікація етнополітичної інтеграції та дезінтеграції. Для сучасного світу вже типовою стала ситуація, за якої держава, що виникла внаслідок етнополітичної дезінтеграції, в тому числі реалізації права народів на самовизначення, бере участь в інтеграційних проєктах, але при цьому продовжує боротися з дезінтеграційними тенденціями, проявами сепаратизму всередині.

Науковий інтерес до цієї проблематики заохочується в НАН України відповідно до постанови Президії НАН України від 30.01.2019 № 30 «Про основні наукові напрями та найважливіші проблеми фундаментальних досліджень у галузі природничих, технічних, суспільних і гуманітарних наук Національної академії наук України на 2019-2023 роки». У напрямі 3.4 «Політико-правові науки» серед пріоритетних комплексних міждисциплінарних досліджень фігурує пункт 3.4.1.29 «Політико-правові засади протидії дезінтеграції та сепаратизму». Саме 


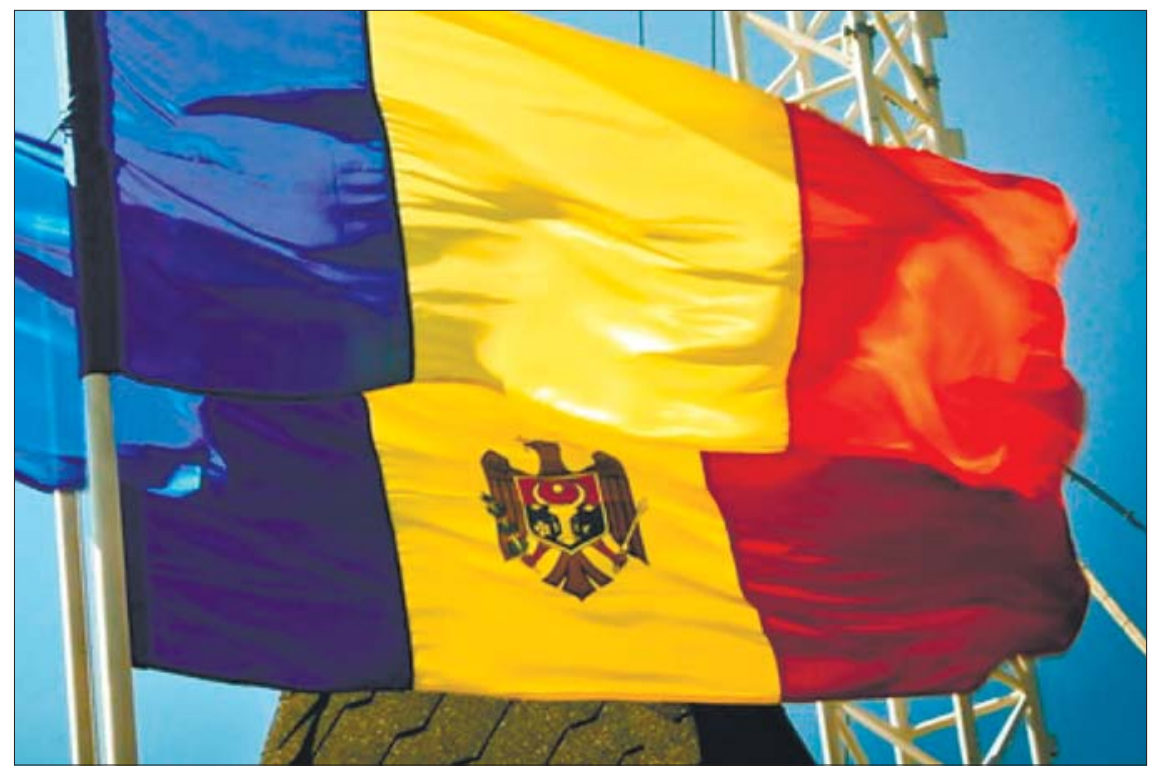

Прикладом нестабільної етнополітичної системи $є$ Молдова. Дезінтеграційноінтеграційні процеси не дозволяють країні просуватися в жодному з напрямів інтеграції/дезінтеграції. Політичний курс на інтеграцію 3 Румунією перешкоджає розв’язанню придністровського конфлікту, реінтеграції територій Придністровської Молдавської Республіки та загрожує подальшою дезінтеграцією - сецесією Гагаузії

міждисциплінарний підхід до дослідження етнополітичної інтеграції та дезінтеграції уможливлює отримання інтегративного знання про характеристики та особливості цих процесів.

Процеси етнополітичної інтеграції та дезінтеграції є взаємопов'язаними, взаємозумовленими, їх інтенсивність зростає в сучасному світі, що стає викликом для етнонаціональної політики держав. Вони мають об'єктивний, об'єктивно-примусовий або примусовий характер, оскільки супроводжують процес еволюції етносу та розвитку держави, можуть бути наслідком цілеспрямованого впливу або комбінації цих чинників. Етнополітична інтеграція та дезінтеграція характеризуються багаторівневістю, нерівномірністю розвитку й реалізації форм, залежністю від політичних, геополітичних, економічних, соціальних та інших внутрішніх та зовнішніх чинників [1].

Діалектична взаємодія інтеграції та дезінтеграції є одним із джерел етнополітичного розвитку. Цим процесам притаманна рівновага, почергова трансформація одного в інший. Етнополітична інтеграція може розвиватися в напрямі зміцнення єдності або, навпаки, трансформуватися в етнополітичну дезінтеграцію. Це дає підстави розглядати державу як етнополітичну систему, що перебуває в стані дезін- теграції, інтеграції або рівноваги. Якщо вона не розпадається, це свідчить про рівновагу інтеграційно-дезінтеграційних тенденцій. Якщо ж до її складу продовжують інтегруватися інші утворення, - про домінування етнополітичної інтеграції над дезінтеграцією. Це дає підстави запропонувати інтегративне визначення етнополітичної інтеграції/дезінтеграції держави як багаторівневого, діалектичного процесу: об'єднання/роз'єднання етнополітичної системи (етнополітичної спільноти (етносу, нації), держави, міждержавного (наддержавного) об'єднання) [2].

Прикладом такої нестабільної етнополітичної системи, яка містить етнічні, територіальні суперечності та залежна від зовнішньополітичних гравців, може бути сусідня Молдова. В цій державі переплелися дезінтеграційноінтеграційні процеси, які врівноважують один одного, не дозволяючи Молдові просуватися в жодному з напрямів інтеграції/дезінтеграції.

Політичний курс на етнополітичну інтеграцію Молдови з Румунією перешкоджає розв'язанню придністровського конфлікту, реінтеграції територій невизнаного утворення та загрожує подальшою дезінтеграцією - сецесією Гагаузії [3]. Уніоністська політика призвела до «демолдовенізації», тобто заперечення мол-

ISSN 1027-3239. Visn. Nac. Acad. Nauk Ukr. 2021. (9) 
довської державності. Румунія, зі свого боку, заохочує інтеграцію обох держав, маючи намір інтегрувати Молдову до свого складу, про що свідчить багаторічна політична риторика еліт та спрощена процедура надання молдованам румунського громадянства.

Між етнічним складом населення держави та ймовірністю виникнення дезінтеграційних тенденцій простежується тісний взаємозв’язок. Сучасні етнополітичні дезінтеграційні процеси в державах Європейського Союзу (референдуми щодо незалежності Шотландії у Великій Британії, Каталонії в Іспанії) свідчать, що поліетнічність є об'єктивним фактором (обов'язковою передумовою) дезінтеграції. Поліетнічні держави, незалежно від особливостей їх формування, залишаються вразливими до етнополітичних відцентрових вимог (автономізації, розширення прав автономії, відокремлення, сепаратизму) з боку етнічних спільнот, тоді як у моноетнічних державах ані становище, ані вплив етноспільнот не сприяють розвитку етнополітичної дезінтеграції [4].

Україна належить до поліетнічних держав, території компактного проживання національних меншин, зокрема угорської, румунської, російської, є вразливими до дезінтеграційних тенденцій.

Етнополітична інтеграція та дезінтеграція завжди сприймалися виключно як об’єктивні закономірності етнонаціонального розвитку людства, проте в сучасному світі ситуація під тиском інформаційних технологій, нових гібридних методів ведення війни змінилася. В жодній концепції, стратегії розвитку держав не зустрічаємо намірів, які стосуються дезінтеграції держави або їі участі в дезінтеграційних проєктах. Однак на практиці виявляється, що зовнішня етнонаціональна політика багатьох країн містить дезінтеграційну складову щодо сусідніх держав, до яких вони мають етнотериторіальні претензії і в яких проживають відповідні національні меншини.

Приклад України демонструє, що етнополітична дезінтеграція з подальшою інтеграцією чи без неї може бути застосована як політична технологія щодо будь-якої держави, яка має ISSN 1027-3239. Вісн. НАН України, 2021, № 9 поліетнічний склад населення, міжетнічні суперечності або суперечності щодо історичної належності територій, населених переважно представниками національних меншин. Оскільки такі характеристики притаманні абсолютній більшості поліетнічних держав, всі вони можуть стати об'єктом етнополітичної дезінтеграції та подальшої інтеграції анексованих територій у позаправовий спосіб. Тому етнополітична інтеграція та дезінтеграція як глобальна взаємопов'язана проблема сучасного світу потребує ретельного наукового вивчення, а також напрацювання політико-правових механізмів стримування та контролю цих процесів.

Необхідність дослідження етнополітичної інтеграції та дезінтеграції в межах вітчизняної етнополітології є беззаперечною - Україна виявилася не готовою протидіяти дезінтеграційним тенденціям і в 2014 р. втратила контроль над частиною своїх територій (Автономною Республікою Крим та частинами Донецької і Луганської областей).

Після Революції Гідності Україна постала перед принципово новими викликами - етнополітичним конфліктом внаслідок агресії Російської Федерації, гібридною війною, анексією Криму та сецесією окремих районів на Сході. Це прояви глибшого за сукупністю причин і наслідків та більш тривалого процесу етнополітичної дезінтеграції.

Дезінтеграція може мати різні форми і прояви, які характеризуються більш звичними для політичного дискурсу означеннями - сепаратизм, агресія, загарбання, іредентизм, анексія, сецесія. В Україні етнополітична дезінтеграція супроводжується воєнними діями, окупацією частини території. Неповне або викривлене розуміння природи етнополітичної дезінтеграціï, ii закономірностей, відсутність інструментів у межах етнонаціональної політики може призвести до подальшого дистанціювання та ізоляції тимчасово окупованих територій (Автономної Республіки Крим та частин Донецької і Луганської областей) від України.

У 2014 р. розпочалася відкрита фаза російської агресії - етнополітичної дезінтеграції 
України, проте їй передувала багаторічна підготовка, підживлення сусідньою державою дезінтеграційних тенденцій та сепаратистських настроїв у середовищі «своїх» національних меншин. Крим і Донбас стали об’єктом уваги Росії через пострадянську та російську ідентичність значної частини населення, яке лояльно ставилося до Російської Федерації [5]. Ця держава у більшості населення цих регіонів асоціювалася з Радянським Союзом як його правонаступниця, а перебування у складі України маркувалося як «тимчасове» або ж як «непорозуміння». Етнонаціональна самоідентифікація і тривала інформаційно-пропагандистська робота з інтеграції населення в «русский мир» відіграли вирішальну роль у тому, що саме ці регіони України було обрано майданчиками для випробування та застосування технології етнополітичної дезінтеграції суверенної держави.

Актуальність проблематики зумовлена тим, що не лише Російська Федерація вдається до цієї політичної технології шляхом втручання у внутрішні справи України, формування відцентрових настроїв у середовищі власної національної меншини через ЗМІ, фінансування громадських організацій національних меншин, фактичною метою діяльності яких є порушення територіальної цілісності України та етнополітична інтеграція регіону проживання власної національної меншини до складу етнічної батьківщини. Угорщина та Румунія проводять подібну політику відповідно на Закарпатті та Буковині.

Наприклад, Угорщина постійно вимагає від України надання автономіі територіям, населеним угорцями, тим самим підживлюючи в них сепаратистські настрої. Одномовна освіта мовою національних меншин тривалий час слугувала підгрунтям для відцентрових тенденцій в Україні, оскільки представники національних меншин повною мірою не інтегрувалися в українське суспільство. Незнання державної мови сприяє ізоляції національних меншин, їх орієнтації виключно на етнічні батьківщини, поширенню сепаратистських настроїв, що в кінцевому підсумку може загрожувати територіальній цілісності України [6].
Відмова від одномовної середньої освіти (лише мовами національних меншин) була продиктована тим, що представники національних меншин у місцях компактного проживання демонструють дуже низький рівень володіння державною мовою. В контексті проведення освітньої реформи в Україні 5 вересня 2017 р. Верховна Рада України ухвалила Закон України «Про освіту», ст. 7 якого визначає мовою освітнього процесу в закладах освіти України державну мову.

Наразі Закарпаття залишається об’єктом етнотериторіальних і етнополітичних претензій Угорщини та Росії, які діють в окремих випадках злагоджено, маючи різні цілі та застосовуючи різні стратегії, що в кінцевому підсумку дестабілізує етнополітичну ситуацію в регіоні та сприяє поширенню сепаратистських настроїв у середовищі національних меншин. Угорщина відкрито проводить поступову етнополітичну інтеграцію населення регіону, жорстко відстоюючи та захищаючи права етнічних угорців, про що свідчить блокування євроатлантичної інтеграції України з вимогою поступок щодо освіти мовами національних меншин, створення в 2018 р. посади урядового уповноваженого, відповідального за розвиток Закарпаття, просування утворення Притисянського виборчого округу на базі районів компактного проживання угорців на Закарпатті для участі їх, зокрема, у виборах до парламенту Угорщини.

Росія приховано використовує так званих політичних русинів, які безпідставно претендують на роль рупора усього закарпатського населення, сприяючи політизації та радикалізації їхніх вимог. Завдання Москви полягає у продовженні дезінтеграції України та послабленні позицій Києва в етнополітичному конфлікті на Сході та Півдні, в погіршенні перспектив деокупації Донбасу та Криму [7].

Зараз перед етнонаціональною політикою України стоїть завдання, з одного боку, блокування дезінтеграційних тенденцій, а з іншого - відновлення територіальної цілісності, повернення контролю над тимчасово окупованими територіями Криму та Донбасу, тобто їх етнополітичної інтеграції. Найчастіше

ISSN 1027-3239. Visn. Nac. Acad. Nauk Ukr. 2021. (9) 


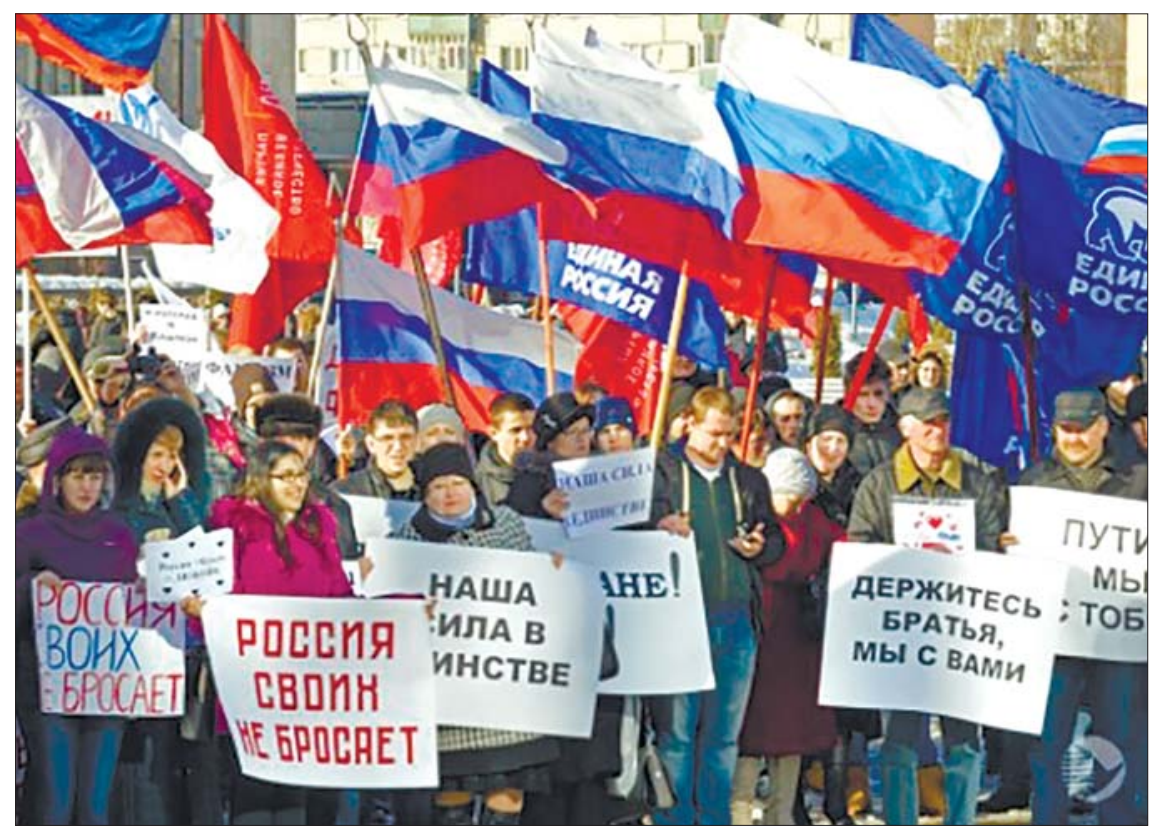

Російська Федерація скористалася політичною кризою в Україні для анексії Автономної Республіки Крим та сецесії окремих районів на Сході. Ці регіони стали об’єктом уваги РФ через пострадянську та російську ідентичність значної частини населення, яке лояльно ставилося до Росії, оскільки сприймало їі як правонаступницю Радянського Союзу, при цьому перебування у складі України маркувалося як «непорозуміння». Нинішнє завдання Москви полягає у продовженні дезінтеграції України та послабленні позицій Києва в етнополітичному конфлікті на Сході та Півдні, в погіршенні перспектив деокупації Донбасу та Криму

в політичному дискурсі активно обговорюється лише один з різновидів етнополітичної інтеграції - реінтеграція. Однак неможливо ставити завдання етнополітичної реінтеграції (повернення) тимчасово окупованих територій без вивчення особливостей, природи, суті та змісту етнополітичної інтеграції загалом.

Україна - не єдина держава, яка зазнала етнополітичної дезінтеграції. У світі є приклади держав, дезінтеграція яких відбулася багато десятиліть тому, породивши феномен розколотих (дезінтегрованих) держав, а врегулювання етнополітичних конфліктів та реінтеграція не завершилися досі. Молдова, Грузія, Азербайджан також втратили частини своїх територій внаслідок етнополітичних конфліктів і намагаються з різним успіхом реінтегрувати їх. Вивчення зарубіжних моделей та стратегій етнополітичної реінтеграції сприятиме більш глибокому науковому розумінню процесів етнополітичної інтеграції та дезінтеграції загалом і напрацюванню практичних рекомендацій для етнонаціональної політики України зокрема.

Розпалювання етнополітичного конфлікту в Україні відбувалося за відпрацьованим у пострадянських державах (Молдові та Грузіі) алгоритмом: регіон, дисперсно або компактно населений національною меншиною, незадоволеною етнонаціональною політикою та/або політичним курсом держави, ззовні підбурюється гібридними засобами до протестів, сецесії та виходу зі складу держави. Невдоволення штучно підсилюється пропагандистськими засобами настільки, що відокремлення подається як найкращий шлях вирішення начебто внутрішнього етнополітичного конфлікту, який набув зовнішньополітичного характеру, як тільки до захисту національної меншини долучилася Російська Федерація, надаючи їй військову, фінансову, політичну підтримку і порушуючи принцип невтручання у внутрішні справи суверенної держави. 
Російська Федерація скористалася політичною кризою для анексії Автономної Республіки Крим та інспірування проявів сепаратизму на Донбасі [8]. Використання русинського руху для дестабілізації етнополітичної ситуації в Закарпатській області, незважаючи на те, що більшість вимог русинів лежить у площині набуття статусу національної меншини в Україні, а не формування територіальної автономії чи виходу зі складу України, стало продовженням застосування РФ етнополітичної технології дезінтеграції України.

Це свідчить про те, що етнополітична дезінтеграція та інтеграція можуть не лише виступати об'єктивними процесами, а й використовуватися 3 маніпулятивною, загарбницькою метою як цілеспрямована етнополітична технологія. Етнополітична технологія - це система засобів, механізмів, процедур, пов'язаних 3 використанням етнічного фактора і спрямованих на досягнення політичних цілей.

Основними передумовами дезінтеграції України стали такі:

1) неефективна етнонаціональна політика України щодо нейтралізації загроз територіальній цілісності та відцентрових тенденцій, зокрема в регіонах, населених національними меншинами, яка полягала у відмежуванні Києва від основних суперечностей і толеруванні іноземної присутності;

2) недієвість, неврегульованість окремих політико-правових інститутів захисту прав національних меншин, зокрема набуття статусу національної меншини, формування національно-культурної автономії, що сприяло політизації етнічності та виникненню дезінтеграційних тенденцій у середовищі національних меншин України;

3) надмірна самостійність регіонів у мовних, етнокультурних питаннях, що призвело до висунення окремими національними меншинами вимог автономізації регіонів проживання, федералізації України як альтернативи унітарному устрою держави;

4) соціально-економічна і політична криза, яка дала підстави регіонам, населеним національними меншинами, сумніватися у легітим- ності нової влади та апелювати до етнічних батьківщин щодо захисту своїх прав;

$5)$ історична пам'ять про перебування у певні історичні періоди регіонів, населених національними меншинами, у складі інших держав (Росії, Румунії, Угорщини);

6) експансіоністська зовнішня політика, зовнішньополітичне втручання сусідніх держав - від вимог надання автономії територіям проживання своїх національних меншин до відкритої агресії та анексії цих територій;

7) етнокультурний, етнополітичний розкол України, криза формування загальнонаціональної ідентичності [9], що призвели до посилення етнорегіональних відмінностей, проведення регіонами власної етнокультурної політики та протиставлення Сходу і Заходу держави.

Оскільки кожен приклад етнополітичної дезінтеграції держави унікальний, політика реінтеграції також має проводитися з урахуванням національних особливостей. Стратегія реінтеграції має обов'язково враховувати дію основних дезінтеграційних чинників і сприяти їх нейтралізації. Етнополітична реінтеграція відрізняється від інших форм реінтеграції визначною роллю в цьому процесі механізмів подолання міжетнічних, лінгвістичних, культурних суперечностей.

Реінтеграція дезінтегрованої держави має відбуватися також з урахуванням різних етнокультурних, політичних середовищ, різного рівня соціально-економічного розвитку, які сформувалися в окремих частинах такої держави. Дезінтеграція та заморожений конфлікт уповільнюють розвиток цих частин.

Головними передумовами реінтеграції дезінтегрованих держав є такі:

- політична воля еліт;

• економічні переваги об'єднання (що засвідчує процес реінтеграції Кіпру);

- нейтралізація агресивних намірів сусідніх держав (на що вказує приклад дезінтеграції Грузії);

- міжнародна співпраця у сфері реінтеграції та міжнародна підтримка територіальної цілісності держави (санкції, миротворчі місії, різні формати переговорів);

ISSN 1027-3239. Visn. Nac. Acad. Nauk Ukr. 2021. (9) 
Напрацювання політикоправових механізмів реінтеграції окупованих територій Донбасу і Криму до складу України є одним 3 найважливіших завдань етнонаціональної політики України. Гальмування процесу реінтеграції призводить до етнополітичного дистанціювання цих територій, ізоляції та подальшої інтеграції їх населення в російський простір. Населення окупованих територій зазнає постійного етнополітичного впливу та тиску з боку РФ, що з плином часу істотно ускладнить процес реінтеграції

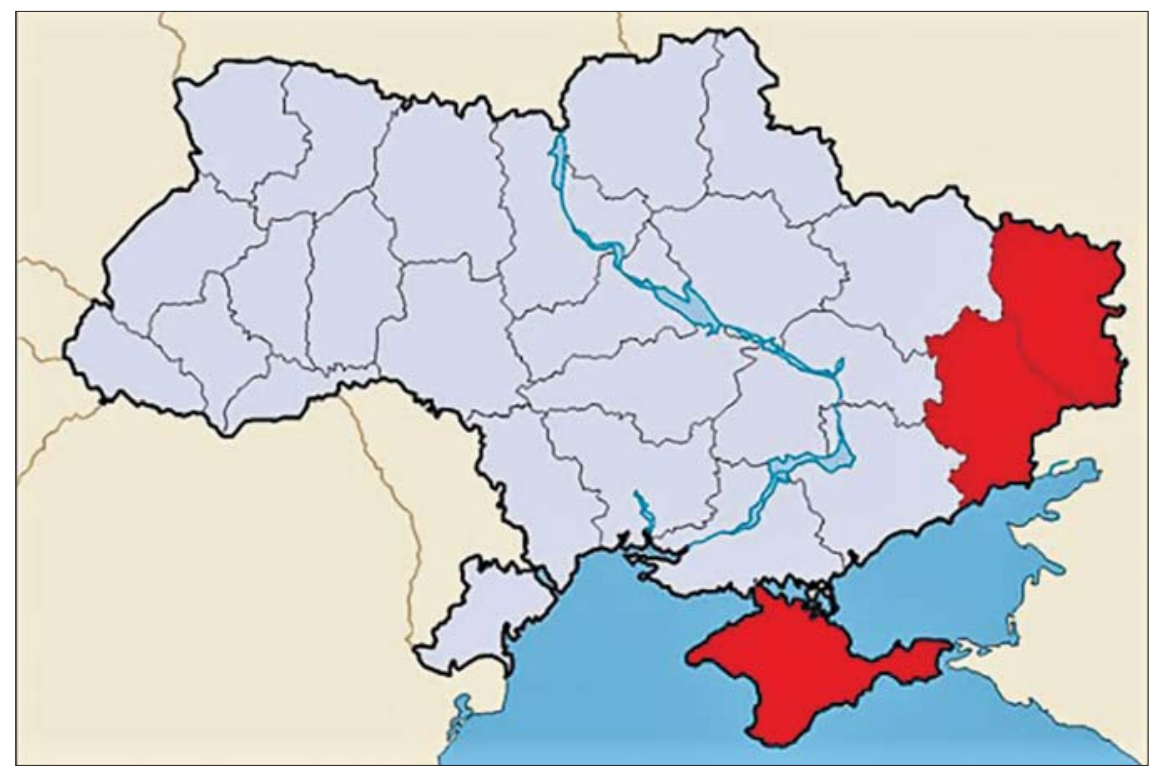

- цілеспрямована етнонаціональна політика, зокрема в питаннях реінтеграції, формування національної єдності, спільної громадянської ідентичності;

- ідеологія спільного майбутнього штучно роз'єднаних частин у межах однієї нації та держави, що грунтується на пріоритеті єдності над роз'єднаністю, пошуку спільних цінностей, у тому числі сформованих історично.

Реінтеграцію України необхідно розглядати в контексті етнонаціональної політики держави, адже саме прорахунки в цій сфері призвели до використання Російською Федерацією фактора етнічної ідентичності як підстави дезінтеграції [10]. Етнонаціональна політика України впродовж перших десятиліть незалежності була й досі залишається не надто виразною, не має належної інституційної і законодавчої бази. Відтак, вона не забезпечила консолідації поліетнічної політичної української нації.

Єдиного центру формування і проведення етнонаціональної політики в Україні немає. Повноваження у цій сфері розпорошені між Міністерством культури та Міністерством 3 питань реінтеграції тимчасово окупованих територій, що перешкоджає їх ефективній та злагодженій реалізації. Законодавча база етно- національної політики потребує осучаснення і вдосконалення, передусім це стосується Закону України «Про національні меншини в Україні» 1992 p.

Україна потребує чіткої концепції державної етнонаціональної політики з детально прописаними принципами, завданнями та цілями, у тому числі щодо забезпечення етнополітичної безпеки, запобігання етнополітичним конфліктам та шляхів їх розв'язання, реалізації політики реінтеграції держави. Законодавча база етнонаціональної політики має розроблятися у тісній співпраці законодавців з науковцями, які постійно аналізують етнополітичну ситуацію в Україні, спираються на вивчення зарубіжного досвіду та мають солідні напрацювання в цій сфері.

Етнополітична реінтеграція - це різновид етнополітичної інтеграції. Етнополітична реінтеграція означає:

1) повторне об'єднання, відновлення цілісності етнополітичної системи (етнополітичної спільноти (етносу, нації), держави, міждержавного (наддержавного) об'єднання), яка раніше дезінтегрувалася;

2) відновлення зв'язків, включення до етнополітичної системи (етнополітичної спільноти 
(етносу, нації), держави, міждержавного (наддержавного) об’єднання) її складової або складових, які раніше відокремилися.

Напрацювання політико-правових механізмів реінтеграції окупованих територій Донбасу і Криму до складу України є одним з найважливіших завдань етнонаціональної політики України. Гальмування процесу реінтеграції призводить до етнополітичного дистанціювання тимчасово окупованих територій від України, ізоляції та подальшої етнополітичної інтеграції їх населення в російський простір, що може стати причиною фактичної втрати окупованих територій назавжди. Населення окупованих територій зазнає постійного етнополітичного впливу та тиску з боку РФ, що з плином часу істотно ускладнить процес реінтеграції. Нелегітимна влада самопроголошених республік намагається блокувати реінтеграційні заходи України, ізолюючи українських громадян, які проживають на окупованій території, від контактів з Україною та налаштовуючи їх вороже до перспективи возз'єднання. 3 часом зв'язок між Україною та окупованими територіями ослаблюється, міжнародні моніторингові організації фіксують там критичне становище із захистом прав людини і громадянина.

Політика реінтеграції передбачає створення відповідної інституційної основи, напрацювання комплексу правових, політичних, етнокультурних, соціальних, економічних реінтеграційних механізмів [11]. Політика реінтеграції України має грунтуватися на системному підході, не обмежуючись таргетним реагуванням окремих інституцій. Різні відомства (спочатку Міністерство з питань тимчасово окупованих територій та внутрішньо переміщених осіб України, потім Міністерство з питань реінтеграції тимчасово окупованих територій, Міністерство інформаційної політики України, Міністерство внутрішніх справ України) вдаються до окремих, не узгоджених між собою реінтеграційних кроків та заходів, які не формують цілісну, системну політику реінтеграції, що перешкоджає досягненню їі кінцевої мети.

На сьогодні громадянське суспільство досягло більших успіхів у реалізації окремих реін- теграційних проєктів, ніж держава. Вирішальними умовами успішної реінтеграції є: координація, узгодження реінтеграційних механізмів та кроків; співпраця органів влади з інституціями громадянського суспільства; міжнародна підтримка реінтеграції України та активна зовнішня політика в цій сфері.

Реінтеграція має стати консолідаційною ідеєю, що об'єднає українську поліетнічну націю. Громадська думка може відіграти вирішальну роль у досягненні мети реінтеграції - відновлення територіальної цілісності України. Незважаючи на те, що етнополітична ситуація та статус окупованої Автономної Республіки Крим суттєво відрізняються від захоплених частин Донецької та Луганської областей, проблема реінтеграції України є нероздільною і повинна вирішуватися комплексно в межах єдиної стратегії.

Відсутність комплексної державної стратегії реінтеграції всіх тимчасового окупованих територій України породжує у громадян зневіру щодо бажання України рухатися в напрямі повернення окупованих територій, формує установку, що держава не здатна провести реінтеграцію через корупцію, неузгодженість та політичні чвари, відсутність належного політико-правового забезпечення процесу реінтеграції. Політика реінтеграції має утверджуватися через налагодження діалогу, формування єдиного етнополітичного простору з урахуванням етнокультурних, історичних особливостей кожного регіону, акумулювання та поширення спільних цінностей, спільного бачення майбутнього України.

Нинішній етап етнополітичної реінтеграції в Україні характеризується такими особливостями:

- необхідність врегулювання етнополітичного конфлікту та стримування збройної агресіі;

- відсутність цілісної стратегії реінтеграції тимчасово окупованого Криму та Донбасу (Україна оголосила про різні моделі та строки їх повернення);

- труднощі формування законодавчої бази (окремо щодо Донбасу, окремо щодо Криму),

ISSN 1027-3239. Visn. Nac. Acad. Nauk Ukr. 2021. (9) 
що породжує колізії та суперечності у визначенні правового статусу тимчасово окупованих територій;

- велика кількість суперечливих планів і проєктів реінтеграції як від органів влади, так і від громадянського суспільства.

Вдосконалення нормативно-правової бази реінтеграції передбачає прийняття низки нормативно-правових актів, які б містили чітке визначення політики реінтеграції, ii етапів, цілей, конкретизували механізми, розмежовували повноваження органів влади у сфері реінтеграції (усували б наявне дублювання), містили законодавче закріплення статусу тимчасово окупованої території України та забезпечення соціальних, економічних, політичних, етнокультурних прав та гарантій громадян, передбачали однакове застосування юридичної термінології.

Закон України «Про особливості державної політики із забезпечення державного суверенітету України на тимчасово окупованих територіях в Донецькій та Луганській областях» став першою спробою комплексного напрацювання законодавчої бази політики реінтеграції. Законом визнано тимчасову окупацію частини території України внаслідок збройної агресії Російської Федерації [12]. У цьому документі Україна підтверджує суверенне право держави на відновлення територіальної цілісності, а також на самооборону відповідно до ст. 51 Статуту ООН, при цьому залишаючись відданою мирному врегулюванню на основі міжнародного права.

Однак його не можна назвати законом про реінтеграцію, оскільки слово «реінтеграція» в ньому взагалі не вживається. Натомість використовується громіздкий термін «державна політика із забезпечення державного суверенітету України на тимчасово окупованих територіях у Донецькій та Луганській областях». Відмова від усталеного терміна «реінтеграція» $\epsilon$ необгрунтованою і спотворює суть поняття реінтеграції. Закон цей рамковий, має загальний декларативний зміст, не містить конкретних реінтеграційних механізмів, а тому потребує прийняття ще багатьох підзаконних актів.
Він більшою мірою фокусується на збройній відсічі агресії, ніж на реінтеграції.

Наразі держава розробляє різні інструменти безпечної реінтеграції тимчасово окупованих територій. Цей процес включає створення міжнародної коаліції для підтримки зусиль України щодо відновлення територіальної цілісності на всіх переговорних майданчиках, поновлення переговорів на міжнародному рівні щодо деокупації Криму, реінтеграцію населення тимчасово окупованих територій, напрацювання механізмів забезпечення інформаційного суверенітету України, доступу до адміністративних послуг мешканців тимчасово окупованих територій, захисту їх прав тощо.

Стратегія деокупації та реінтеграції тимчасово окупованої території Автономної Республіки Крим та міста Севастополя, затверджена Указом Президента у березні 2021 р., є позитивним зрушенням. У цьому документі визначено комплекс заходів дипломатичного, військового, економічного, інформаційного, гуманітарного та іншого характеру, спрямованих на відновлення територіальної цілісності, державного суверенітету України у міжнародно визнаних кордонах шляхом деокупації та реінтеграції Криму. Серед конкретних механізмів - Кримська платформа як ключовий зовнішньополітичний інструмент консолідації міжнародних зусиль, спрямованих на деокупацію та подолання наслідків, спричинених тимчасовою окупацією; заходи у сфері перехідного правосуддя, зокрема щодо відшкодування шкоди, заподіяної у зв'язку зі збройною агресією Російської Федерації, збройним конфліктом, тимчасовою окупацією території України (реєстр заподіяної шкоди державі Україна, їі громадянам і юридичним особам) тощо [13]. Проте ця Стратегія є радше комплексом заходів з відновлення зв'язків та захисту прав, ніж комплексною стратегією з етнополітичної реінтеграції. Вона не дає відповіді на запитання, як Україна реінтегруватиме Крим, наскільки привабливу перспективу може запропонувати його населенню в разі етнополітичної реінтеграції.

Отже, етнополітична дезінтеграція у вигляді збройного конфлікту і тимчасової окупації 
територій та інтеграція у вигляді реінтеграції Криму та Донбасу стали потужними викликами для етнонаціональної політики України. Водночас ці події спричинили позитивні зрушення, зокрема такі як підвищення інституційної спроможності органів влади, зростання активності та контролю з боку громадянського суспільства, поліпшення правового забезпечення у протидії гібридним загрозам та дезінтеграційним тенденціям в етнополітичній сфеpi, формування етнонаціональної стійкості - здатності держави у взаємодії з громадянським суспільством зберігати стійкість до зовнішніх та внутрішніх деструктивних впливів [14], оперативно реагувати на асиметричні загрози, ефективно функціонувати в дезінтеграційний і постдезінтеграційний період, а також відновлюватися після деструктивних дезінтеграційних процесів завдяки інтенсифікації процесів етнополітичної інтеграції, як внутрішньої (консолідації), так і зовнішньої (реінтеграції тимчасово окупованих територій).

\section{REFERENCES}

\section{[СПИСОК ЛІТЕРАТУРИ]}

1. Whitman K.M. Euroscepticism as a manifestation of disintegration tendencies in the EU. Scientific Bulletin of the International Humanities University. Series: History. Philosophy. Politology. 2017. (13): 8-12. (in Ukrainian). http:// vestnik-humanities.mgu.od.ua/archive/2017/13/4.pdf

[Вітман К.М. Євроскептицизм як прояв дезінтеграційних тенденцій в ЄС. Науковий вісник Міжнародного гуманітарного університету. Сер. Історія. Філософія. Політологія. 2017. № 13. С. 8-12.]

2. Yavir V.A. Ethnopolitical integration and disintegration in the modern world:political and legal concept (Etnopolitychna intehratsiia ta dezintehratsiia u suchasnomu sviti: polityko-pravovyi kontsept). Kyiv: Logos, 2018. P. 135 (in Ukrainian).

[Явір В.А. Етнополітична інтеграція та дезінтегращія у сучасному світі: політико-правовий конщепт. Київ: Логос, 2018. С. 135.]

3. Ciurea C. Moldova between West and East: which comes first, Euro-integration or conflict settlement? International Issues \& Slovak Foreign Policy Affairs. 2013. 22(4): 71-83.

4. Yavir V.A. Polyethnicity of the state as a factor of ethnopolitical disintegration. Evropský Politický a Právní Diskurz. 2017. 4(6): 128-131. (in Ukrainian). https://eppd13.cz/wp-content/uploads/2017/2017-4-6/21.pdf

[Явір В.А. Поліетнічність держави як фактор етнополітичної дезінтеграції. Evropský Politický a Právní Diskurz. 2017. T. 4, № 6. C. 128-131.]

5. Political and legal mechanisms for preventing separatism in a democratic society (Polityko-pravovi mekhanizmy zapobihannia separatyzmu v demokratychnomu suspilstvi). Kyiv: Koretsky Institute of State and Law of the NAS of Ukraine, 2014. (in Ukrainian).

[Політико-правові механізми запобігання сепаратизму в демократичному суспільстві: наукова записка. Київ: Інститут держави і права ім. В.М. Корецького НАН України, 2014.]

6. Ethnocultural autonomy as an institute for ensuring the rights of national minorities: world experience and Ukraine (Etnokulturna avtonomiia yak instytut zabezpechennia prav natsionalnykh menshyn: svitovyi dosvid i Ukraina). Kyiv: Koretsky Institute of State and Law of the NAS of Ukraine, 2018. (in Ukrainian).

[Етнокультурна автономія як інститут забезпечення прав національних меншин: світовий досвід $і$ Украйна: наукова записка. Київ: Інститут держави і права ім. В.М. Корецького НАН України, 2018.]

7. Yavir V.A. Transcarpathia as an object of ethnoterritorial claims of Hungary and Russia: a comparative analysis of strategies and goals. Political Life. 2018. (3): 78-83. DOI: https://doi.org/10.31558/2519-2949.2018.3.13

[Явір В.А. Закарпаття як об’єкт етнотериторіальних претензій Угорщини та Росії: порівняльний аналіз стратегій та цілей. Політичне життя. 2018. № 3. С. 78-83.]

8. Aslanov S.A. Risks of ethnopolitical instability: attempts of ethnopolitical disintegration of Ukraine. Politology bulletin. 2014. 74: 322-331. (in Ukrainian).

[Асланов С.А. Ризики етнополітичної нестабільності: спроби етнополітичної дезінтеграції України. Політологічний вісник. 2014. Вип. 74. С. 322-331.]

9. Ukraine: the way to the consolidation of society (Ukraina: shliakh do konsolidatsii suspilstva). National Report. Kyiv, 2017. (in Ukrainian). https://ipiend.gov.ua/wp-content/uploads/2018/07/national_report_230.pdf 
[Україна: шлях до консолідащії суспільства: національна доповідь. Київ, 2017.]

10. Model of ethnonational policy for the reintegration of Donbass and Crimea (Model etnonatsionalnoi polityky dlia reintehratsii Donbasu i Krymu): Kyiv: Koretsky Institute of State and Law of the NAS of Ukraine, 2016. (in Ukrainian). [Модель етнонащіональної політики для реінтегращї Донбасу і Криму: наукова записка. Київ: Ін-т держави $\mathrm{i}$ права ім. В.М. Корецького НАН України, 2016.]

11. Reintegration. Effective approaches. International Organization for Migration, 2015. https://www.iom.int/sites/default/files/migrated_files/What-We-Do/docs/Reintegration-Position-Paper-final.pdf

12. On the peculiarities of the state policy to ensure the state sovereignty of Ukraine in the temporarily occupied territories in Donetsk and Luhansk regions. The Law of Ukraine of 18.01.2018 No. 2268-VIII. (in Ukrainian). https:// zakon.rada.gov.ua/laws/show/2268-19\#Text

[Про особливості державної політики із забезпечення державного суверенітету України на тимчасово окупованих територіях в Донецькій та Луганській областях: Закон України від 18.01.2018 № 2268-VIII.]

13. On the decision of the National Security and Defense Council of Ukraine of March 11, 2021 «On the Strategy of deoccupation and reintegration of the temporarily occupied territory of the Autonomous Republic of Crimea and the city of Sevastopol»: Decree of the President of Ukraine of 24.03.2021 No. 117/2021. (in Ukrainian). https://zakon. rada.gov.ua/laws/show/117/2021\#Text

[Про рішення Ради національної безпеки і оборони України від 11 березня 2021 року «Про Стратегію деокупації та реінтеграції тимчасово окупованої території Автономної Республіки Крим та міста Севастополя»: Указ Президента України від 24.03.2021 № 117/2021.]

14. Reznikova O. Ensuring national security and national stability: common and distinctive features. Visnyk of the Lviv University. Philosophical Political studies. 2018. 19: 170-175. (in Ukrainian). http://fps-visnyk.lnu.lviv.ua/archive/19_2018/24.pdf

[Резнікова О. Забезпечення національної безпеки і національної стійкості: спільні й відмінні риси. Вісник Львівського університету. Серія філософсько-політологічні студіі. 2018. Вип. 19. С. 170-175.]

Vera A. Yavir

ORCID: https://orcid.org/0000-0002-1854-5012

Koretsky Institute of State and Law

of the National Academy of Sciences of Ukraine, Kyiv, Ukraine

INTEGRATION AND DISINTEGRATION OF THE STATE

AS A CHALLENGE FOR THE ETHNONATIONAL POLICY OF UKRAINE

According to the materials of report at the meeting of the Presidium of NAS of Ukraine, July 7, 2021

The intensification of the processes of ethnopolitical integration and disintegration in the modern world, their dialectical interrelation and interdependence are studied. The preconditions, factors and peculiarities of the open phase of ethnopolitical disintegration of Ukraine, which began in 2014, are revealed. Manifestations of disintegration challenges that threaten the territorial integrity of the state, in particular, interference in the internal affairs by Ukraine's neighboring countries (Hungary, Russian Federation) under the pretext of protecting the rights of national minorities are examined. The process of ethnopolitical reintegration is analyzed and the consideration of reintegration policy in the context of the state ethnonational policy of Ukraine is substantiated. The current state, legal framework, political peculiarities of reintegration are studied, as well as recommendations for successful reintegration of the temporarily occupied territories of Crimea and Donbas are given.

Keyzords: ethnopolitical integration, ethnopolitical disintegration, ethnonational policy, national minorities, ethnopolitical conflict, reintegration. 